\title{
Adopsi Inovasi Layanan Online di Dinas Kependudukan dan Pencatatan Sipil Kota Samarinda
}

\section{Adoption of Online Service Innovation at Departement of Population and Civil Registration Samarinda City}

\begin{abstract}
Ainun Nimatu Rohmah*), Khansa Yumna Abiyyu, Cindy Elisa, Nurasimah, Natalia Lembang Pasapan, Safika,
\end{abstract} Muhammad Nur Firdaus, Noviani Reksa Permatasari

Program Studi Ilmu Komunikasi Fakultas Ilmu Sosial dan Ilmu Politik, Universitas Mulawarman, Jalan Kuaro, Kota Samarinda, Kalimantan Timur 75119

${ }^{*}$ E-mail korespondensi: ainunrohmah@,fisip.unmul.ac.id

Diterima: 08 Jan 2022 | Disetujui: 09 Februari 2022 | Publikasi online: 22 Februari 2022

\section{ABSTRACT}

The Smart City concept is an effort to use technology to optimize services to the community. One of the forms of Smart City is an online service for society's affairs by government institutions. This study aims to find out how innovation adopting process of online service via WhatsApp by the Department of Population and Civil Registration (Disdukcapil) of Samarinda City employing the Diffusion Theory of Innovation. This study uses a descriptive qualitative approach. The data were gathered using field research techniques, including observation and in-depth interviews with purposive sampling technique to determine informants. The result of this study is that the online service via WhatsApp Disdukcapil was successfully adopted from the knowledge stage to the confirmation stage because it was considered as needed and more flexible by the informants. Pamphlets and banners are the essential channels for disseminating initial information on the innovation. The results show that interpersonal communication between the society and government representatives acts as the vital process of exchanging information for adopters to obtain additional information. Informants' ability of the technology affects their perception of relative advantage, suitability, and complexity of the innovation.

Kata kunci: adoption, diffusion of innovation theory, e-government, online service, smart city

\section{ABSTRAK}

Konsep Smart City hadir sebagai upaya pemanfaatan teknologi untuk mengoptimalkan pelayanan kepada masyarakat. Salah satu bentuknya yaitu berupa pelayanan online untuk berbagai urusan masyarakat oleh institusi pemerintah. Penelitian ini dilakukan untuk mengetahui bagaimana proses adopsi inovasi pelayanan online via WhatsApp yang dilakukan Dinasi Kependudukan dan Pencatatan Sipil (Disdukcapil) Kota Samarinda dengan menggunakan Teori Difusi Inovasi. Penelitian ini menggunakan pendekatan kualitatif deskriptif. Data diambil dengan teknik penelitian lapangan, meliputi observasi dan wawancara mendalam dengan teknik purposive sampling untuk menetapkan informan. Hasil dari penelitian ini adalah pelayanan online via WhatsApp Disdukcapil berhasil diadopsi dari tahap pengetahuan hingga tahap konfirmasi, karena dianggap sesuai kebutuhan dan lebih fleksibel oleh informan. Pamflet dan banner menjadi saluran komunikasi yang berperan sebagai alat penyebarluasan informasi awal. Diketahui pula komunikasi interpersonal antara masyarakat dan perwakilan pemerintah berperan sebagai proses pertukaran informasi bagi adopter guna mendapatkan informasi tambahan. Kemampuan informan dalam menggunakan teknologi mempengaruhi persepsinya dalam melihat derajat keuntungan relatif, kesesuaian, dan kerumitan dari inovasi.

Kata kunci: adopsi, e-government, layanan online, smart city, teori difusi inovasi

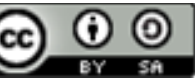

Content from this work may be used under the terms of the Creative Commons Attribution-ShareAlike 4.0 International. Any further distribution of this work must maintain attribution to the author(s) and the title of the work, journal citation and DOI.

Published under Department of Communication and Community Development Science, IPB University and in association with Forum Komunikasi Pembangunan Indonesia and Asosiasi Penerbitan Jurnal Komunikasi Indonesia.

E-ISSN: 2442-4102 | P-ISSN: 1693-3699 


\section{PENDAHULUAN}

Perkembangan teknologi informasi dan komunikasi (TIK) termasuk kehadiran internet merupakan alasan utama perlunya perubahan dalam model pembangunan sebuah negara (Rusadi, 2014). Melalui TIK, pemerintah dapat diuntungkan karena sistem online membuat hubungan dengan masyarakat menjadi efisien dan transparan, sehingga dapat meningkatkan kemudahan dan kualitas layanan yang menjadi syarat utama dalam tata laksana yang baik atau good governance (Batool et al., 2021). Untuk mewujudkannya, dibutuhkan komunikasi dalam perspektif pembangunan guna menyampaikan gagasan dan keterampilan pembangunan kepada masyarakat yang menjadi sasaran agar dapat memahami, menerima dan berpartisipasi dalam pembangunan (Saleh, 2010). Menurut Andrian (2020), komunikasi pembangunan adalah upaya yang cepat dan efektif untuk membawa perubahan kesadaran dan membangun rasa kebersamaan untuk meningkatkan kualitas hidup masyarakat.

Smart city atau kota cerdas merupakan sebuah inovasi dalam pembangunan modern. Konsep ini bertujuan untuk memenuhi kebutuhan masyarakat dan meningkatkan efisiensi dengan pemanfaatan TIK di bidang pelayanan masyarakat (Utomo \& Hariadi, 2016). Menurut Kementerian Dalam Negeri Republik Indonesia, konsep ini berfokus pada tata kelola kota yang terintegrasi dengan area pembangunan yang komprehensif serta kemajuan TIK untuk mewujudkan perencanaan dan pembangunan kota yang layak, modern dan maju, serta mendorong produktivitas dan daya saing ekonomi, serta manifestasi dari Indonesia smart nation (Hasibuan \& Sulaiman, 2019). Sebagai sebuah inovasi, model komunikasi pembangunan yang dibutuhkan dalam pengembangan smart city adalah model difusi inovasi yang menyasar pada perilaku individu terhadap inovasi (Rusadi, 2014). Perspektif komunikasi pembangunan ini menekankan ide pembangunan berasal dari masyarakat untuk membangun kapasitas dirinya dengan aliran informasi bersifat horizontal (Rogers, 2003), sehingga masyarakat tidak semata diperlakukan sebagai objek melainkan lebih sebagai subjek yang terlibat atas dasar kemauan dan kebutuhan diri bukan karena mobilisasi pemerintah (Soetomo, 2013).

Terdapat 6 faktor yang menjadi prioritas dalam pengembangan smart city, yaitu smart governance (pemerintahan yang cerdas), smart branding (branding daerah yang cerdas), smart economy (ekonomi cerdas), smart living (kelayakan hidup cerdas), smart environment (pemeliharaan lingkungan cerdas) dan smart society (masyarakat cerdas) (Frost \& Sullivan, 2014). Salah satu fondasi penting dari smart city adalah terdapatnya e-government yang baik (Arjita, 2017) sebagai perwujudan indeks kapasitas smart city (manusia, ekonomi, kehidupan, lingkungan, mobilitas dan pemerintahan) (Giffinger et al., 2007). E-government didefinisikan sebagai penyelenggaraan pemerintahan dengan memanfaatkan TIK guna mendorong kinerja pemerintah, memenuhi kebutuhan masyarakat serta sebagai bentuk transparansi dan akuntabilitas informasi menuju good governance (Widodo, 2016). Indrajit (dalam Akadun, 2009) menjelaskan bahwa sistem pemerintahan ini berorientasi pada pelayanan masyarakat dan penyediaan informasi serta pelayanan publik berbasis internet.

Menurut Mechant \& Walravens (2018), dalam kaitannya dengan disiplin ilmu komunikasi, terdapat tiga tema besar studi yang mengaitkan konsep e-government dan smart city yaitu data (data), pemerintahan (governance) dan partisipasi (participation). Dalam hal data, kedua konsep tersebut menekankan pentingnya bentuk-bentuk atau saluran yang lebih cerdas untuk menghubungkan pemerintah dengan stakeholder dan sebaliknya. Tema kedua menekankan pada adanya perubahan bentuk dan peran pemerintahan yang lebih responsif dan mempromosikan keaktifan warga. Sebagai media komunikasi pembangunan, peran pemimpin yang berfokus pada pengembangan smart city sebagai saluran komunikasi interaktif dengan masyarakat menjadi penting (Imran \& Armawan, 2019). Sementara, tema ketiga tentang partisipasi menekankan pada bagaimana pemerintah lokal mengembangkan bentuk-bentuk kolaborasi menggunakan teknologi, termasuk dalam hal pelayanan. Perencanaan partisipasi yang berdasar pada saluran informasi dan komunikasi merupakan bagian integral dalam konsep smart city (Szarek-Iwaniuk \& Senetra, 2020).

Lim et al. (2019) menemukan bahwa implementasi smart city di negara berkembang cenderung memberikan hasil negatif yang disebabkan masih adanya keraguan atas efektivitas konsep ini. Budaya masyarakat juga menjadi hambatan dalam difusi inovasi pembangunan (Rusadi, 2014). Budaya dapat dipandang sebagai kebiasaan yang mengemas perilaku masyarakat sehari-hari, termasuk belum terbiasanya masyarakat memanfaatkan internet untuk berbagai urusan administrasi pemerintahan (Istyanto \& Nasrulloh, 2019). Hal ini juga disebabkan penggunaan internet di negara berkembang masih belum merata, sebagai contoh di Indonesia 55,7\% penetrasi internet terdapat di pulau Jawa 
sementara daerah lain seperti pulau Kalimantan hanya 6,6\% (Asosiasi Penyedia Jaringan Internet Indonesia, 2019).

Selain kesenjangan digital, kurangnya kesiapan masyarakat untuk mengadopsi e-government dan kurangnya kepercayaan terhadap inovasi ini juga menghambat implementasi e-government di Indonesia (Sabani, Deng, et al., 2019). Masalah lain yang ditemui antara lain aspek sumber daya manusia dengan kompetensi yang kurang memadai (Meiyanti et al., 2019), serta rendahnya pendidikan, literasi digital dan inisiatif kesadaran warga (Arief \& Yunus Abbas, 2021). Selain itu, penelitian Tryanti \& Frinaldi (2019) menemukan bahwa faktor interpersonal aktor yaitu kurangnya ketelitian, kedisiplinan dan keramahan dari aparatur juga menjadi kendala utama selain faktor teknis dalam implementasi e-government. Hal menarik menjadi temuan Istyanto \& Nasrulloh (2019) bahwa latar belakang usia serta aspek kepercayaan dan kualitas informasi memengaruhi motivasi dalam menggunakan layanan berbasis e-government. Selain itu, kemampuan pengguna menjadi hal yang penting untuk ditingkatkan dalam desain layanan online, disamping perlunya menerima feedback dari pengguna layanan e-government (Lazar et al., 2017). Meski demikian, Sabani et al. (2019) melihat implementasi e-government dibutuhkan oleh Indonesia, khususnya untuk mendukung penuntasan korupsi yang telah menjadi masalah epidemik pada sektor pemerintahan.

Konsep smart city turut diimplementasikan di Kota Samarinda, Provinsi Kalimantan Timur. Berdasarkan surat Nomor 265/KOMINFO/DJAI/AI.01.05/05/2017, Kota Samarinda dinyatakan lulus dan terpilih dalam program smart city yang menjadi bagian dari Gerakan Menuju 100 Smart City Indonesia oleh Kementerian Komunikasi dan Informasi Republik Indonesia (Ghofar, 2017). Atas dasar keputusan tersebut, Pemerintah Kota Samarinda mengeluarkan Peraturan Walikota Samarinda Nomor 8 Tahun 2018 tentang Masterplan Samarinda Smart City agar menjadi dasar pelaksana terwujudnya visi Samarinda Smart City yaitu Samarinda sebagai Kota Tepian Cerdas yang terdepan di Kalimantan. Bidang pelayanan masyarakat masih menjadi masalah di Kota Samarinda (Juniriantio \& Fadhliana, 2019). Oleh karena itu, dalam mengimplementasikan program smart city persiapan dilakukan mulai dari tahapan paling bawah diantaranya mengacu pada dimensi kebijakan, SDM ITK, infrastruktur ITK sampai pada tahap aplikasi pelayanan publik (Taufik, 2017), salah satunya dalam bidang administrasi kependudukan.

Untuk memaksimalkan pelayanan administrasi kependudukan yang lebih efektif dan efisien dalam kerangka smart city, Disdukcapil Kota Samarinda menerapkan layanan bernama Go Digital. Layanan ini diharapkan dapat memberi kemudahan kepada masyarakat dalam memperoleh informasi secara cepat. Layanan ini ditetapkan melalui Surat Edaran Nomor 470/08.a/100.16 tentang Sistem Pelayanan Disdukcapil Samarinda Go Digital oleh Kepala Disdukcapil Samarinda. Dalam surat edaran tersebut dijelaskan bahwa dalam rangka mengembangkan kualitas pelayanan publik secara tertib, transparan dalam percepatan pelayanan maka perlu menghadirkan sebuah inovasi sebagai suatu sistem yang memberikan kepastian kepada masyarakat. Inovasi program Disdukcapil berbasis Go Digital ini salah satunya berupa layanan via aplikasi WhatsApp. Layanan ini membuat masyarakat yang memiliki keperluan terkait dokumen kependudukan mengurus dokumen kependudukan tidak harus lagi datang ke Disdukcapil (Doni, 2021).

Dalam kerangka e-government, pelayanan via aplikasi WhatsApp merupakan bentuk implementasi model Government to Citizen (G2C). G2C bertujuan menyediakan akses informasi dan layanan yang dapat memangkas rantai birokrasi, mengeliminir praktek korupsi serta meningkatkan transparansi dan akuntabilitas pemerintah (Indrajit, 2004). Kondisi pandemi Covid-19 menjadi momentum adopsi program Go Digital pelayanan via WhatsApp yang berdampak pada penurunan masuknya berkas permohonan secara langsung atau walk in customer (WIC). Berdasarkan hasil observasi awal Kepala Disdukcapil Kota Samarinda, Abdullah, diketahui bahwa sejak tahun 2020 terdapat penurunan jumlah berkas hampir 40\%. Disdukcapil Kota Samarinda biasanya bisa melayani hingga 4.500 berkas, berkurang menjadi 1.500 berkas masuk setiap harinya (Rahayu, 2021).

Teori Difusi Inovasi merupakan kerangka konsep yang sering digunakan dalam menyelidiki adopsi inovasi. Teori ini juga dapat diaplikasikan dalam implementasi e-government (Akça \& Özer, 2014). Difusi didefinisikan sebagai proses komunikasi sebuah inovasi melalui saluran tertentu oleh anggota sistem sosial dalam waktu tertentu (Rogers, 2003). Sementara, inovasi menurut Rogers (2003) dapat berbentuk gagasan, tindakan atau barang yang memiliki sifat kebaruan. Dalam konteks penelitian ini, inovasi yang dimaksud adalah inovasi layanan online Go Digital yang dilakukan Disdukcapil Kota Samarinda melalui aplikasi WhatsApp. 
Proses difusi inovasi melalui lima tahapan, yaitu: pengetahuan (knowledge), persuasi (persuasion), keputusan (decision), implementasi (implementation), dan konfirmasi (confirmation) (Ardianto et al., 2014). Tahap pengetahuan adalah dimana terdapat pengetahuan dan pemahaman individu mengenai sebuah inovasi beserta fungsinya. Tahap persuasi dimana individu memutuskan sikap antara setuju ataupun tidak setuju dari sebuah inovasi. Tahap keputusan merupakan tindakan yang dibentuk individu dalam proses pemilihan antara menerima atau menolak inovasi. Pada tahap implementasi, individu menggunakan inovasi untuk mempelajari lebih jauh tentang inovasi sekaligus meyakinkan penilaiannya. Tahap komunikasi yang terakhir adalah konfirmasi dimana warga mengevaluasi dampak dari keputusan inovasi individu mencari penguatan (dukungan) terhadap pilihannya (Sahin, 2006).

Penelitian dalam ranah difusi inovasi terkait implementasi e-government di Indonesia lebih banyak mengkaji program-program aplikasi berbasis website seperti penelitian Istyanto \& Nasrulloh (2019), Wibowo (2019), Rahmawati \& Fatchuriza (2021) dan Fazil et al. (2018), sementara penelitian terkait inovasi dalam bentuk gagasan masih belum banyak dilakukan. Oleh karena itu, penelitian ini berfokus pada layanan online via WhatsApp yang pada dasarnya merupakan gagasan perubahan metode layanan dari berbasis tatap muka menjadi online dalam rangka praktek e-government. Penggunaan TIK dalam kerangka pembangunan ini merupakan kelanjutan model komunikasi untuk pembangunan, yang bertolak dari kehidupan masyarakat dengan bercirikan pembangunan mikro (Rusadi, 2014). Sebagaimana Laenens et al. (2018) menyatakan bahwa masyarakat lebih memilih saluran komunikasi lokal ketika berinteraksi dengan pemerintah lokal, regional dan nasional, serta lebih menyukai jika informasi yang berdampak bagi mereka diinformasikan secara personal.

Di sisi lain, pengembangan TIK juga menghadirkan eksklusivitas dimana gagap teknologi masih menjadi masalah dalam urusan administrasi pemerintahan (Fazil et al., 2018). Beberapa kelompok masyarakat memerlukan waktu lama untuk mengadopsi inovasi tertentu, oleh karenanya difusi inovasi yang terjadi sangat tergantung pada sistem dan struktur sosial dalam masyarakat (Rogers, 2003). Penetrasi internet, literasi digital dan kesiapan masyarakat yang berbeda di berbagai wilayah dapat menjadi hambatan dalam proses komunikasi pembangunan dalam konteks e-government. Oleh karena itu, peneliti memandang perlu untuk menelisik masalah-masalah apa yang muncul dalam proses difusi inovasi layanan online melalui WhatsApp dalam praktek e-government dalam rangka menyukseskan upaya implementasi e-government menuju smart city di Kota Samarinda. Berdasarkan pemaparan di atas, penelitian ini akan berfokus untuk menjawab rumusan masalah berikut: bagaimana proses difusi inovasi layanan online berbasis WhatsApp oleh Dinas Kependudukan dan Pencatatan Sipil di Kota Samarinda?

\section{METODE PENELITIAN}

Jenis penelitian ini adalah kualitatif dengan sumber data utama ialah kata-kata dan tindakan (Creswell, 2018). Peneliti memilih penelitian kualitatif deskriptif dengan alasan untuk mengetahui dan menjabarkan secara mendalam proses difusi inovasi layanan online Dinas Kependudukan dan Pencatatan Sipil di Kota Samarinda.

Penelitian ini menggunakan teknik pengumpulan data berupa penelitian lapangan (research field). Observasi, wawancara mendalam (in depth interview), arsip dan dokumen lain yang terkait merupakan teknik pengumpulan data yang digunakan. Peneliti menggunakan teknik purposive sampling dalam menetapkan informan yang dianggap mampu memberikan informasi yang dibutuhkan (Sugiyono, 2017), antara lain pernah mengurus administrasi di Disdukcapil Kota Samarinda dalam enam bulan terakhir serta telah menggunakan layanan online Disdukcapil Kota Samarinda. Keterbatasan kondisi pandemi menjadi alasan peneliti tidak mencari informan di lapangan secara tidak sengaja (accidental), melainkan dari lingkungan para peneliti yang memenuhi kriteria tersebut. Berdasarkan proses yang dilakukan, wawancara dilakukan pada tujuh orang sebagai informan pengguna layanan online via WhatsApp Disdukcapil Kota Samarinda, serta Kepala Bidang Pelayanan Pendaftaran Penduduk Disdukcapil kota Samarinda. Pelaksanaan penelitian ini dilakukan melalui wawancara langsung maupun via telepon.

Analisis data yang digunakan adalah analisis kualitatif deskriptif model interaktif Miles \& Huberman (1994). Data kualitatif berupa transkrip wawancara yang dikumpulkan kemudian diabstraksi atau diringkas oleh peneliti dengan mereduksi data-data yang tidak berkaitan, untuk kemudian disusun kode-kode dan tema berdasarkan fokus penelitian. Setelah itu, data disajikan dalam bentuk teks naratif dan bentuk lainnya untuk kemudian dilakukan penarikan kesimpulan yang sekaligus memverifikasi proses analisis. Dalam melaksanakan penelitian ini, strategi validitas yang digunakan antara lain 
triangulasi sumber data informasi, mengklarifikasi bias peneliti dan peer debriefing serta menyajikan informasi yang berbeda atas tema (Creswell, 2018). Peneliti juga melakukan prosedur reliabilitas kualitatif dengan memastikan tidak ada kesalahan transkripsi, memastikan proses pengkodean sesuai dengan definisi serta cross-check kode-kode yang dikembangkan peneliti lain (Creswell, 2018).

\section{HASIL DAN PEMBAHASAN}

\section{Perkembangan Inovasi Layanan Online Aplikasi WhatsApp}

Rogers (2003) menjelaskan proses perkembangan inovasi terdiri atas keputusan, aktivitas dan dampak yang terjadi dari pemahaman masalah atas kebutuhan atau masalah melalui proses difusi dan adopsi inovasi oleh pengguna. Proses perkembangan inovasi layanan online via WhatsApp dimulai dari kesadaran Dinas Kependudukan dan Pencatatan Sipil Kota Samarinda terkait masalah efisiensi dan efektivitas yang ditemui dalam aktivitas pelayanan sehari-hari (recognizing a problem), yaitu menumpuknya antrian dan inefisiensi dalam proses layanan tatap muka. Teknologi dipandang sebagai solusi atas masalah tersebut. Oleh karena itu, Dinas Kependudukan dan Pencatatan Sipil Kota

Samarinda menciptakan website layanan online melalui http://disdukcapil.samarindakota.go.id/pelayanan_online.

Namun, dalam perkembangannya sebuah inovasi harus memperhatikan variabel penting terkait karakteristik dari pengadopsi (Dearing \& Cox, 2018), dalam hal ini adalah masyarakat. Warga Kota Samarinda dipandang belum terbiasa menggunakan website untuk berbagai kebutuhan urusan administrasi, sehingga Dinas Kependudukan dan Pencatatan Sipil Kota Samarinda memandang dibutuhkan saluran lain yang lebih mudah digunakan oleh masyarakat, yaitu melalui aplikasi WhatsApp. Dengan memanfaatkan aplikasi ini, gagasan layanan online bisa tetap diimplementasikan sebagai bagian dari Go Digital.

Pemilihan layanan melalui aplikasi WhatsApp merupakan gagasan yang sesuai dengan pengadopsi potensial program Go Digital. Aplikasi yang bersifat personal lebih disukai oleh warga untuk berkomunikasi dengan pemerintah sebagaimana studi yang dilakukan Laenens et al., (2018). Selain itu, saluran ini memungkinkan komunikasi yang interaktif sebagai salah satu elemen penting dalam implementasi smart city menurut Imran \& Armawan (2019). Aplikasi WhatsApp merupakan saluran komunikasi penting untuk mendukung aktivitas seseorang sehari-hari khususnya yang terbiasa menggunakan ponsel pintar (smartphone) dan terhubung dengan internet. Menurut Kepala Dinas Kependudukan dan Pencatatan Sipil Kota Samarinda, Abdullah, proses layanan via WhatsApp sangat mudah dan efisien karena masyarakat tidak perlu datang ke kantor dan hanya perlu mengunduh atau memfoto dokumen persyaratan sesuai kebutuhan berkas, dan setelah selesai berkas akan dikirim menggunakan kurir.

Meski demikian, penelitian ini menemukan bahwa layanan online melalui aplikasi WhatsApp oleh Disdukcapil Kota Samarinda masih terbatas untuk melayani kebutuhan administrasi dan tidak diperkenalkan sebagai saluran keluhan, saran maupun kritik warga terhadap layanan Pemerintah. Padahal feedback terhadap layanan merupakan wujud partisipasi dalam pemerintahan cerdas yang terkoneksi dan integratif sebagai kualitas penting terwujudnya smart city (Arafah \& Winarso, 2020; Lazar et al., 2017; Szarek-Iwaniuk \& Senetra, 2020). Hal ini terkait pula dengan hasil temuan Kaya et al. (2020) bahwa media sosial penting untuk mendukung praktek e-government karena dapat menyajikan dialog dua-arah yaitu metode komunikasi yang lebih disukai oleh pengambil keputusan inovasi karena aspek popularitas dan aksesabilitas serta kebutuhan masyarakat.

Jika ditinjau dalam kajian komunikasi terkait smart city dan e-government sebagaimana disampaikan Mechant \& Walravens (2018), gagasan layanan online via WhatsApp ini berada pada tema kedua yaitu pemerintah. Pemerintah atau dalam hal ini Disdukcapil Kota Samarinda memahami perlunya menggunakan saluran interpersonal untuk terhubung dan melayani masyarakat. Disdukcapil Kota Samarinda telah berupaya merubah bentuk layanan yang dipandang inefisien secara tatap muka dan hadir dengan layanan yang lebih responsif untuk memotivasi warga menjadi lebih aktif dalam praktek e-government. Meskipun demikian, berdasarkan hasil penelitian ini layanan online via WhatsApp oleh Disdukcapil Kota Samarinda masih belum optimal dikarenakan kurangnya strategi implementasi yang terencana dengan baik. Hasil penelitian ini menunjukkan masih terdapat kendala-kendala terkait kesiapan dan kemampuan penggunaan teknologi oleh sasaran penerima, konsistensi dan kapabilitas aktor personal dibalik layanan ini dan belum adanya bentuk dialog melalui layanan ini yang 
mendorong partisipasi dan kolaborasi masyarakat, yang belum diantisipasi oleh Disdukcapil Kota Samarinda.

\section{Proses Difusi dan Adopsi Inovasi Layanan Online via WhatsApp}

Teori Difusi Inovasi menjelaskan bahwa terdapat langkah-langkah atau tahapan dalam mengadopsi sebuah inovasi. Adopsi dipahami sebagai suatu kegiatan yang dilakukan individu terhadap inovasi semenjak individu tersebut mengenal, menerima, hingga pada tahap menerapkannya yang berlangsung pada diri seseorang dalam menentukan keputusan yakni berupa alternatif pilihan menerima atau menolak adopsi (Rogers, 2003). Hasil dan pembahasan terkait tahapan-tahapan ini disajikan sebagai berikut:

Tahap Pengetahuan (Knowledge).Tahap pengetahuan (knowledge) adalah keadaan individu yang menyadari adanya sebuah inovasi dan bagaimana pemahaman individu dari fungsi inovasi tersebut. Tahap pengetahuan ini dimulai ketika munculnya kesadaran seseorang terhadap inovasi yang diberikan. Kesadaran yang dimaksud berkenaan pada bentuk inovasi dan manfaat yang diperoleh ketika inovasi tersebut diadopsi. Rogers (2003) menjelaskan terdapat tiga bentuk pengetahuan tentang inovasi, yaitu kesadaran-pengetahuan (awareness-knowledge) terkait eksistensi sebuah inovasi, pengetahuan tentang bagaimana menggunakan (how-to knowledge), dan pengetahuan tentang bagaimana sebuah inovasi bekerja (principles-knowledge).

Dalam hal kesadaran-pengetahuan (awareness-knowledge), 6 dari 7 informan menyatakan mengetahui eksistensi layanan ini melalui orang lain dan 1 orang setelah datang langsung ke kantor Disdukcapil Kota Samarinda. Hasil penelitian menunjukkan, informasi terkait layanan online via WhatsApp tersebar melalui tiga medium, yaitu: dari mulut ke mulut (word of mouth), melalui media komunikasi yang berada di lingkungan Kantor Disdukcapil dan kegiatan-kegiatan insidental. Sebagaimana diungkapkan oleh informan 1 dari kutipan wawancara berikut:

"Saya mengetahui layanan online via WhatsApp ini karena sebelumnya pernah melakukan layanan ini. Pertamanya saya datang ke Kantor [Disduk] Capil ternyata pendaftarannya melalui online," (A, Kantor Disdukcapil Kota Samarinda, 24/11/21)

Hal serupa diungkapkan oleh informan 2 sebagai berikut:

"Saya pernah mengetahui inovasi dalam pelayanan online terutama dalam menggunakan aplikasi whatsapp yang di Disdukcapil itu. Saya tau kemarin itu pas saya vaksin pertama, tapi nomor NIK saya tidak terdaftar jadi dikasih tau oleh kampus saya disuruh daftar lewat WhatsApp gitu," (VA, Kantor Disdukcapil Kota Samarinda, 24/11/21)

Rogers (2003) menjelaskan proses perkembangan inovasi terdiri atas keputusan, aktivitas dan dampak yang terjadi dari pemahaman masalah atas kebutuhan atau masalah melalui proses difusi dan adopsi inovasi oleh pengguna. Proses perkembangan inovasi layanan online via WhatsApp dimulai dari kesadaran Dinas Kependudukan dan Pencatatan Sipil Kota Samarinda terkait masalah efisiensi dan efektivitas yang ditemui dalam aktivitas pelayanan sehari-hari (recognizing a problem), yaitu menumpuknya antrian dan inefisiensi dalam proses layanan tatap muka. Teknologi dipandang sebagai solusi atas masalah tersebut. Oleh karena itu, Dinas Kependudukan dan Pencatatan Sipil Kota Samarinda menciptakan website layanan online melalui http://disdukcapil.samarindakota.go.id/pelayanan_online.

Dalam perkembangannya sebuah inovasi harus memperhatikan variabel penting terkait karakteristik dari pengadopsi (Dearing \& Cox, 2018), dalam hal ini adalah masyarakat. Warga Kota Samarinda dipandang belum terbiasa menggunakan website untuk berbagai kebutuhan urusan administrasi, sehingga Dinas Kependudukan dan Pencatatan Sipil Kota Samarinda memandang dibutuhkan saluran lain yang lebih mudah digunakan oleh masyarakat, yaitu melalui aplikasi WhatsApp. Dengan memanfaatkan aplikasi ini, gagasan layanan online bisa tetap diimplementasikan sebagai bagian dari Go Digital.

Pemilihan layanan melalui aplikasi WhatsApp merupakan gagasan yang sesuai dengan pengadopsi potensial program Go Digital. Aplikasi yang bersifat personal lebih disukai oleh warga untuk berkomunikasi dengan pemerintah sebagaimana studi yang dilakukan Laenens et al., (2018). Selain itu, saluran ini memungkinkan komunikasi yang interaktif sebagai salah satu elemen penting dalam implementasi smart city menurut Imran \& Armawan (2019). Aplikasi WhatsApp merupakan saluran komunikasi penting untuk mendukung aktivitas seseorang sehari-hari khususnya yang terbiasa 
menggunakan ponsel pintar (smartphone) dan terhubung dengan internet. Menurut Kepala Dinas Kependudukan dan Pencatatan Sipil Kota Samarinda, Abdullah, proses layanan via WhatsApp sangat mudah dan efisien karena masyarakat tidak perlu datang ke kantor dan hanya perlu mengunduh atau memfoto dokumen persyaratan sesuai kebutuhan berkas, dan setelah selesai berkas akan dikirim menggunakan kurir.

Meski demikian, penelitian ini menemukan bahwa layanan online melalui aplikasi WhatsApp oleh Disdukcapil Kota Samarinda masih terbatas untuk melayani kebutuhan administrasi dan tidak diperkenalkan sebagai saluran keluhan, saran maupun kritik warga terhadap layanan Pemerintah. Padahal feedback terhadap layanan merupakan wujud partisipasi dalam pemerintahan cerdas yang terkoneksi dan integratif sebagai kualitas penting terwujudnya smart city (Arafah \& Winarso, 2020; Lazar et al., 2017; Szarek-Iwaniuk \& Senetra, 2020). Hal ini terkait pula dengan hasil temuan Kaya et al. (2020) bahwa media sosial penting untuk mendukung praktek e-government karena dapat menyajikan dialog dua-arah yaitu metode komunikasi yang lebih disukai oleh pengambil keputusan inovasi karena aspek popularitas dan aksesabilitas serta kebutuhan masyarakat.

Jika ditinjau dalam kajian komunikasi terkait smart city dan e-government sebagaimana disampaikan Mechant \& Walravens (2018), gagasan layanan online via WhatsApp ini berada pada tema kedua yaitu pemerintah. Pemerintah atau dalam hal ini Disdukcapil Kota Samarinda memahami perlunya menggunakan saluran interpersonal untuk terhubung dan melayani masyarakat. Disdukcapil Kota Samarinda telah berupaya merubah bentuk layanan yang dipandang inefisien secara tatap muka dan hadir dengan layanan yang lebih responsif untuk memotivasi warga menjadi lebih aktif dalam praktek e-government. Meskipun demikian, berdasarkan hasil penelitian ini layanan online via WhatsApp oleh Disdukcapil Kota Samarinda masih belum optimal dikarenakan kurangnya strategi implementasi yang terencana dengan baik. Hasil penelitian ini menunjukkan masih terdapat kendala-kendala terkait kesiapan dan kemampuan penggunaan teknologi oleh sasaran penerima, konsistensi dan kapabilitas aktor personal dibalik layanan ini dan belum adanya bentuk dialog melalui layanan ini yang mendorong partisipasi dan kolaborasi masyarakat, yang belum diantisipasi oleh Disdukcapil Kota Samarinda.

"Saya pikir lebih mudah menggunakan pelayanan via WhatsApp. Namun, namanya orang awam atau belum terlalu paham akan teknologi pasti lebih mudah menggunakan pelayanan secara langsung, ” (S, Kantor Disdukcapil Kota Samarinda, 25/11/21).

Hasil penelitian ini menunjukkan adanya kesadaran dari informan bahwa implementasi layanan online via WhatsApp sangat tergantung dengan kemampuan individu menggunakan teknologi informasi dan komunikasi. Sebagaimana hasil penelitian terdahulu (Arief \& Yunus Abbas, 2021; Sabani, Deng, et al., 2019), kesiapan individu khususnya dalam literasi digital dapat menjadi penghambat dalam proses difusi inovasi ini. Para informan menilai bahwa layanan online ini akan rumit bagi individu yang tidak terbiasa menggunakan internet, hal ini terkait pula dengan faktor kebiasaan atau tradisi sebagaimana hasil temuan Istyanto \& Nasrulloh (2019). Hasil penelitian ini tidak mengonfirmasi temuan Laenens et al. (2018) bahwa saluran interpersonal lebih disukai masyarakat dalam berkomunikasi dengan pemerintah. Bagi para informan, layanan online via WhatsApp yang merupakan jalur komunikasi interpersonal hanya memberi manfaat efisiensi (bisa dilakukan dari mana saja tidak perlu langsung ke kantor) namun tidak dalam hal efektivitas. Hal ini bisa jadi dikarenakan ketiadaan aspek dialog pada layanan ini.

Sementara itu, terkait pengetahuan tentang bagaimana sebuah inovasi bekerja (principles-knowledge), kendala yang ditemui oleh para informan bukan pada penggunaan WhatsApp melainkan pada prosedur layanan online yang membutuhkan pengunggahan data-data dalam bentuk file yang harus di-scan. Seluruh informan menilai layanan online via WhatsApp memberikan respon yang lama. Hal ini menjadi alasan beberapa informan memandang layanan tatap muka lebih baik dibandingkan layanan online. Hal ini mengonfirmasi penelitian terdahulu (Aji \& Dharmawan, 2020; Meiyanti et al., 2019; Tryanti \& Frinaldi, 2019) yang menemukan bahwa proses difusi inovasi sangat dipengaruhi oleh konsistensi dan kapabilitas aktor personal dibalik inovasi tersebut.

Para informan mengetahui inovasi layanan online sebagai suatu rancangan ide yang dimunculkan oleh Disdukcapil Kota Samarinda melalui beragam saluran komunikasi. Saluran komunikasi tersebut diantaranya ialah petugas Disdukcapil, banner/spanduk dan pihak kampus sebagai lembaga pendidikan tinggi pada kegiatan-kegiatan insidental. Kemunculan inovasi ini mengarahkan informan untuk selanjutnya mencari informasi terkait pelaksanaan program dan bagaimana prosedur yang dilakukan, 
serta manfaat yang akan didapat. Masyarakat yang sadar akan manfaat berarti paham akan kebutuhannya yang bisa dengan mudah mengurus administrasi kependudukan seperti KTP, Akta Kelahiran, Akta Kematian dan lain sebagainya terutama pada kondisi pandemi yang mengharuskan segala aktivitas dilakukan dari rumah.

Tahap Persuasi (persuasion). Tahap persuasi terjadi ketika sudah terdapat sedikit pengetahuan terkait keberadaan inovasi. Pada tahap ini, sikap menyukai atau tidak menyukai akan dibentuk (Rogers, 2003). Informasi akan lebih digali guna mengurangi ketidakpastian terkait keuntungan relatif dari inovasi tersebut (Effendy, 2003). Berbeda dengan tahap pengetahuan yang mengandalkan fungsi kognitif dalam aktivitas mental, maka tahap persuasi didasari atas fungsi afektif, sehingga secara psikologis seseorang terlibat dengan inovasi. Seseorang secara aktif mencari informasi tentang ide baru, memutuskan pesan apa (what) yang mereka pandang dapat dipercaya dan memutuskan bagaimana (how) mereka menginterpretasi informasi yang diterima (Rogers, 2003). Kemudian, persepsi selektif (selective perception) yang akan menentukan perilaku individu pada tahap persuasi sehingga terbentuk sikap menyukai atau tidak menyukai terhadap inovasi.

Proses ini dimulai saat timbul kebutuhan individu akan layanan Disdukcapil. Kebutuhan itulah yang kemudian memancing individu mencari tahu prosedur penyelesaian urusan mereka. Dua dari tujuh informan mengaku mendapatkan informasi layanan online ketika datang ke kantor Disdukcapil langsung, sehingga informasi tersebut dianggap kredibel. Sementara, lima informan memperoleh informasi dari pihak lain. Para informan yang menerima informasi dari pihak lain ini tetap mengecek kebenaran dengan datang langsung ke Disdukcapil langsung, sebagaimana pernyataan informan 4:

"Saya tetap mencari [tahu] inovasi ini dengan datang langsung ke tempat Disdukcapil agar lebih jelas,” (S, Kantor Disdukcapil Kota Samarinda, 25/11/21).

Hal serupa dilakukan oleh informan 5, sebagai berikut:

"Ya, karena pada saat itu panitia hanya memberikan kontak disdukcapil pusat maka dari itu saya inisiatif untuk mendatangi kantor disdukcapil secara langsung dan di depan kantor terdapat papan informasi yang berisi tahapan menggunakan inovasi ini,” (AN, Kantor Disdukcapil Kota Samarinda, 26/11/21)

Saluran komunikasi (media) dapat mempengaruhi terjadinya pembentukan sikap oleh sasaran inovasi dalam tahap persuasi. Pada tahap ini pula, terjadi proses pembentukan persepsi selektif (selective perception) yang menentukan kecenderungan seseorang terhadap inovasi dan berlanjut pada pembentukan perilaku (Rogers, 2003). Pihak Disdukcapil menggunakan berbagai saluran komunikasi guna menyebarluaskan informasi terkait inovasi yang ada. Saluran komunikasi ibarat kendaraan untuk mengantarkan pesan dan informasi terkait inovasi dari komunikator ke komunikan. Dari hasil penelitian diketahui bahwa informan menilai informasi langsung dari Disdukcapil adalah yang paling kredibel. Para informan yang mengetahui informasi layanan online dari orang lain hanya mendapatkan sebagian informasi saja, sehingga butuh penjelasan yang lebih detil secara langsung terkait kebutuhan masing-masing. Salah satu informan menyatakan beberapa kebutuhan dapat diproses secara online, namun untuk kebutuhan yang mendesak ia akan langsung ke kantor.

Media komunikasi cetak seperti banner dan pamflet yang disediakan oleh pihak Disdukcapil menjadi sumber informasi tambahan terkait inovasi layanan online via WhatsApp. Banner dan pamflet yang disediakan berisi tentang tata cara dalam menggunakan pelayanan online via WhatsApp serta nomor WhatsApp yang harus dihubungi. Sayangnya, media komunikasi ini hanya disediakan dan dipasang di area kantor Disdukcapil, maupun pada kegiatan-kegiatan yang terkait dengan kebutuhan administrasi masyarakat. Walaupun Disdukcapil Kota Samarinda sudah mendistribusikan informasi menggunakan berbagai saluran komunikasi yang ada, proses adopsi inovasi sangat bergantung pada insiatif dan keinginan adopter untuk mencari informasi lebih lanjut. Seseorang yang aktif menggali informasi, maka proses adopsi inovasi yang terjadi akan semakin baik (As'Adi, 2020). Berdasarkan hasil penelitian ini, diketahui bahwa pesan-pesan yang disebarluaskan melalui saluran-saluran komunikasi tersebut kemudian menjadi salah satu pertimbangan masyarakat untuk mengadopsi layanan online via WhatsApp.

Berdasarkan hasil penelitian, diketahui pula bahwa Disdukcapil Kota Samarinda belum memanfaatkan saluran komunikasi yang lebih luas seperti media massa maupun media sosial untuk mempromosikan layanan online ini. Berdasarkan observasi peneliti, promosi layanan melalui media online atau media massa hanya berupa berita ketika layanan ini dirilis dimana Kepala Disdukcapil Kota Samarinda 
mengajak masyarakat untuk menggunakan layanan ini, bukan dalam bentuk advertorial yang dilakukan berulang. Sebenarnya, hal ini merupakan media promosi yang penting sesuai hasil penelitian Aji \& Dharmawan (2020) bahwa ajakan dari pemimpin komunitas atau pemimpin daerah akan mempengaruhi kecepatan proses difusi inovasi. Namun, para informan dalam penelitian ini menyatakan tidak mendapatkan informasi layanan online ini dari media massa atau media online.

Selain itu, diketahui bahwa komunikasi interpersonal sangat berperan dalam mempengaruhi sikap dan perilaku seseorang terhadap sebuah inovasi. Deddy Mulyana menjelaskan komunikasi interpersonal merupakan komunikasi yang terjadi secara langsung oleh para pelaku komunikasi, dimana setiap pelaku komunikasi dapat menangkap reaksi pelaku komunikasi lainnya secara langsung (Aw, 2016). Sebagaimana diungkapkan oleh informan 2:

"Semua informasi didapat dari tetangga tersebut, karena sudah memiliki pengalaman dan suratnya sudah jadi. Oleh sebab itu, tata cara penggunaan inovasi pelayanan via whatsapp mengikuti instruksi dari tetangga tersebut," (VA, Kantor Disdukcapil Kota Samarinda, 24/11/21).

Hasil wawancara diatas menjelaskan bahwa komunikasi interpersonal berperan penting dalam penyebaran informasi lebih lanjut terkait inovasi yang ada. Sebagaimana tujuan komunikasi interpersonal sendiri ialah untuk mempengaruhi sikap dan tingkah laku (Aw, 2016). Proses komunikasi interpersonal terjadi secara dialogis, dimana terdapat interaksi di dalamnya. Interaksi yang terjadi dalam proses komunikasi yang dialogis ada usaha untuk mencapai mutual understanding dan menumbuhkan empati. Hasil penelitian ini mengonfirmasi hasil penelitian sebelumnya tentang pentingnya komunikasi dua arah dalam proses difusi inovasi.

Tahap Pengambilan Keputusan (Decision). Proses pengambilan keputusan adopsi inovasi dimulai ketika seseorang melibatkan dirinya kepada aktivitas yang mengarah kepada pilihan untuk menerima atau menolak sebuah inovasi yang ditawarkan (Febriana \& Setiawan, 2016). Sebelum memutuskan untuk mengadopsi sebuah inovasi, terdapat beberapa sifat-sifat inovasi yang menjadi pertimbangan guna mendukung keputusan yang akan diambil. Sifat-sifat tersebut yakni keuntungan relatif (relative advantage), kesesuaian (compatibility), kerumitan (complexity), tahapan dicoba (trialability), kemungkinan diamati (observability) (Rogers, 2003).

Berdasarkan hasil penelitian ini, elemen-elemen yang paling menonjol dalam mendukung keputusan pengadopsi adalah keuntungan relatif, kesesuaian dan kemudahan penggunaan dari inovasi pelayanan online via WhatsApp. Hal ini mendukung penelitian terdahulu (Lean et al., 2020; Weerakkody et al., 2016) yang menemukan bahwa keuntungan relatif merupakan faktor paling mendukung intensi calon pengadopsi untuk mengadopsi inovasi. Namun, temuan berbeda dari dua studi tersebut juga diperoleh pada penelitian ini, dimana kemungkinan diamati tidak tampak memengaruhi intensi informan dalam menggunakan inovasi. Penelitian ini juga mengonfirmasi hasil Weerakkody et al. (2016) bahwa sifat kesesuaian mempengaruhi intensi untuk menggunakan inovasi. Kesesuaian berkaitan pandangan dimana sebuah inovasi dianggap sejalan dengan nilai, pengalaman dan kebutuhan adopter. Sementara, penelitian Lean et al. (2020) menemukan bahwa kerumitan menjadi faktor lain yang memengaruhi intensi adopsi inovasi selaras dengan temuan pada penelitian ini. Kerumitan merupakan sifat inovasi yang berkaitan dengan sulit atau tidaknya sebuah inovasi untuk dimengerti (Ardianto et al., 2014).

Pada tahap ini, para informan mulai menyadari kegunaan, keuntungan, dan kesesuaian inovasi layanan online via WhatsApp dengan kebutuhan saat ini. Sebagaimana hasil wawancara dari informan 5 menyatakan:

"Menurut saya, inovasi ini sesuai dengan kebutuhan. Apalagi saya seorang mahasiswa yang punya banyak kesibukan. Maka, akan lebih mudah ketika saya menggunakan inovasi ini tanpa harus keluar rumah,” (EM, Kantor Disdukcapil Kota Samarinda, 26/11/21).

Berdasarkan hasil wawancara, seluruh informan telah menyadari sifat-sifat inovasi pelayanan online via WhatsApp. Informan yang paham dan mampu menggunakan teknologi cenderung lebih menyukai inovasi pelayanan online via WhatsApp. Sedangkan, informan yang masih awam teknologi merasa inovasi ini rumit dan membingungkan. Hal ini selaras dengan Pengambilan keputusan oleh adopter dilakukan setelah ia mengetahui informasi mengenai inovasi ini. Salah satunya diungkapkan oleh informan 2 dan 5, dari kutipan wawancara sebagai berikut: 
"Tidak membutuhkan waktu lama, karena faktor kebutuhan yang ingin cepat maka saya mengambil keputusan bahwa inovasi ini lebih mudah," (VA, Kantor Disdukcapil Kota Samarinda, 24/11/21).

"Mau tidak mau harus menerima karena sudah menjadi ketentuan untuk bisa mengurus aktivasi NIK," (EM, Kantor Disdukcapil Kota Samarinda, 26/11/21).

Sebagian informan memutuskan untuk menerima inovasi ini karena keterpaksaan dari ketentuan yang ada dalam menggunakan layanan Disdukcapil Kota Samarinda. Hal ini tidak selaras dengan prinsip komunikasi pembangunan yang seharusnya berasal dari determinasi diri masyarakat untuk meningkatkan kapasitas dirinya dalam pembangunan sebagaimana dijelaskan Soetomo (2013). Selain itu, ketiadaan opinion leader yang memengaruhi pengambilan keputusan juga menjadi aspek penting berdasarkan hasil penelitian ini.

Tahap Implementasi (Implementation). Pada tahap Implementasi atau pelaksanaan inovasi yang telah diterima akan mulai digunakannya dengan melibatkan perubahan perilaku yang jelas (Rogers, 2003). Seorang akan melihat teknologi sesuai dengan manfaat dan mereka cenderung membandingkan dengan risiko dalam penggunaannya (Fakhruzzaman \& Dimitrova, 2020). Pada tahap ini, para informan membandingkan efektivitas dan efisiensi layanan online dibanding layanan secara langsung dari beberapa aspek yang secara umum memberikan gambaran beragam. Informan dengan latar belakang generasi $\mathrm{z}$, cenderung memandang layanan online lebih mudah, sebagaimana pernyataan Informan 5:

"Lebih mudah yang online karena dimana juga bisa lebih menghemat waktu, hanya melalui pengisian data diri tanpa harus datang langsung ke tempatnya," (EM, Kantor Disdukcapil Kota Samarinda, 26/11/21).

Sementara informan dengan latar belakang generasi y dan lebih tua tidak menampik efisiensi layanan online, namun cenderung lebih percaya pada proses tatap muka dengan datang langsung ke kantor. Hal ini ditunjukkan dari pernyataan informan 7 :

"Lebih mudah secara langsung, karena jika melalui WhatsApp cukup ribet karena harus foto dulu, scanner dan lain-lain," (SA, Kantor Disdukcapil Kota Samarinda, 26/11/21).

Pada tahap ini masih terdapat ketidakyakinan atas konsekuensi inovasi meskipun telah menggunakan inovasi tersebut sebelumnya (Rogers, 2003). Berdasarkan hasil penelitian, secara umum informan generasi z lebih mudah mengadopsi layanan online ini karena menilai layanan online lebih efisien waktu dan tenaga dimana seluruh kebutuhan administrasi Disdukcapil Kota Samarinda bisa diselesaikan melalui gadget dari mana saja. Sementara, informan generasi milenial dan lebih tua cenderung menilai layanan tatap muka lebih efektif dan efisien. Meskipun demikian, penelitian ini tidak membahas khusus persepsi berdasarkan latar belakang pengadopsi inovasi.

Beberapa informan menyatakan keberatan jika layanan diubah seluruhnya menjadi online, salah satunya dikemukakan oleh informan 1:

“... Tapi yang menjadi permasalahan itu harusnya dipilah yang mana yang online yang mana yang offline karena kan kadang ada yang memang perlu nggak online. Kalau ini kan rata-rata hantam lurus semua, semua di-online-kan," (A, Kantor Disdukcapil Kota Samarinda, 24/11/21)

Hasil ini menunjukkan perlunya komunikan atau pengelola inovasi untuk memperhatikan transisi perubahan dibarengi dengan sosialisasi yang optimal terkait inovasi layanan online. Jika proses transisi dalam difusi inovasi tidak diperhatikan dapat menimbulkan masalah dalam penerimaan inovasi itu sendiri (Laenens et al., 2018). Pada tahapan ini informan mulai menerapkan penggunaan inovasi di kehidupan sehari-hari mereka yaitu sebagai alternatif untuk mendapatkan pelayanan dengan mudah yang bisa dilakukan dimana saja melalui gawai. Hasil penelitian ini selaras dengan Istyanto \& Nasrulloh (2019) yang menemukan bahwa latar belakang usia dimana masyarakat dengan usia generasi milenial atau lebih tua cenderung menyukai layanan tatap muka.

Tahap Konfirmasi (Confirmation). Tahap konfirmasi adakah ketika seseorang membuat keputusan final dalam menentukan apakah keberadaan inovasi diterima atau mengakhiri dengan maksud menolak keberadaan inovasi. Adopsi dapat dihentikan jika terdapat inovasi yang lebih baik, kinerja inovasi dianggap tidak memuaskan, serta muncul rasa kecewa dalam penggunaan inovasi yang ditawarkan (Abdullah dalam Putra, 2018). Pada tahap konfirmasi ini Individu akan mencari alasan untuk 
penguatan atau dukungan atas keputusan yang telah dibuatnya, baik itu menerima inovasi ataupun menolak inovasi ini.

Ketidakcocokan (dissonance) yang dianalisis pada tahap konfirmasi bisa berkurang jika individu menyadari kebutuhannya dan mencari tahu inovasi untuk memenuhi kebutuhan tersebut, mengetahui dan lebih menyukai inovasi baru yang belum diadopsi, serta setelah keputusan inovasi individu merasa aman dan yakin (Rogers, 2003). Penguatan keputusan tampak pada pernyataan Informan 1 yang menemukan ketidakcocokan (dissonance) dari inovasi layanan online via WhatsApp:

"Kalau saya selain mengurus aktivasi yah saya menerima karena lebih mudah. Yang bikin sulit itu pelayanan aktivasinya yang online. Tapi kalau untuk pembuatan kartu keluarga dan lain sebagainya lebih enak menggunakan via WhatsApp." (A, Kantor Disdukcapil Kota Samarinda, 24/11/21).

Pernyataan tersebut diatas menggambarkan ketidakcocokan informan terhadap layanan online via WhatsApp untuk beberapa kebutuhannya. Sementara, informan 7 menyatakan tidak dapat menerima inovasi ini dengan penguatan dari segi efisiensi waktu sesuai kebutuhannya sebagaimana pernyataan berikut:

"Tidak, terutama untuk saya yang belum terlalu paham menggunakan teknologi. Sebenarnya inovasi ini lebih mudah bagi orang yang tidak gaptek. Dan apabila menggunakan inovasi ini biasanya jadinya lambat pasti harus menunggu 1-2 minggu baru bisa dikirim. Tetapi apabila kita melalui pelayanan secara langsung apabila hari ini kita memasukkan berkas, pasti besoknya udah jadi dan bisa diambil," (SA, Kantor Disdukcapil Kota Samarinda, 26/11/21).

Berbeda dengan informan 1 dan 7, informan lainnya menyatakan dapat menerima inovasi layanan online via WhatsApp dengan mudah. Penguatan adopsi dari para informan ini berhubungan dengan kemampuan individu yang sudah terbiasa dalam menggunakan teknologi, sehingga layanan online melalui aplikasi WhatsApp dipandang lebih memudahkan urusan administrasi Disdukcapil. Hal ini diungkapkan Informan 5 sebagai berikut:

"Saya langsung bisa menerima, karena saya kira lebih mudah dan tidak memakan waktu lebih lama serta fleksibel bisa dilakukan dimanapun dan kapanpun," (S, Kantor Disdukcapil Kota Samarinda, ...).

Hasil penelitian ini mengonfirmasi temuan Istyanto \& Nasrulloh (2019) terkait aspek kemudahan, kepercayaan dan kualitas infomasi melalui layanan tatap muka yang dipandang lebih baik sebagai faktor kurangnya motivasi masyarakat menggunakan layanan online. Namun, penelitian ini juga menemukan bahwa informan dengan latar belakang usia muda (generasi z) cenderung lebih terbuka untuk mengadopsi layanan online. Keterkaitan antara usia atau generasi usia belum banyak menjadi fokus penelitian terkait adopsi inovasi dalam bidang e-government. Temuan ini dapat menjadi perhatian penting pada penelitian serupa selanjutnya.

\section{KESIMPULAN}

Inovasi pelayanan online via WhatsApp Disdukcapil Kota Samarinda bertujuan untuk memenuhi kebutuhan masyarakat dengan meningkatkan pemanfaatan teknologi informasi dan komunikasi di bidang pelayanan masyarakat. Inovasi ini menghadirkan cara baru sekaligus solusi dalam memberikan pelayanan kepada masyarakat di tengah situasi pandemi.

Penelitian ini menemukan fakta beragam terkait proses adopsi masyarakat terhadap layanan online via WhatsApp. Pada tahap pengetahuan, penyebarluasan informasi masih terbatas di lingkungan Kantor Disdukcapil Kota Samarinda dan media komunikasi yang ada pada kegiatan-kegiatan tertentu. Pihak Disdukcapil Kota Samarinda belum memanfaatkan media massa maupun online untuk mempromosikan layanan ini, sehingga masyarakat umumnya tetap ke kantor Disdukcapil yang dipandang sebagai sumber kredibel agar teryakinkan terhadap inovasi ini. Pada tahap persuasi, komunikasi interpersonal dengan seseorang yang sudah menggunakan layanan online via Whatsapp dan pamflet serta banner yang sudah tersedia menjadi pilihan pengadopsi untuk menggali informasi tambahan. Pada tahap pengambilan keputusan, para informan mempertimbangkan keuntungan relatif, kerumitan, dan kesesuaian dalam mengadopsi inovasi. Kemudahan dan fleksibilitas inovasi menjadi alasan diterimanya inovasi ini. Sementara, pada tahap konfirmasi sebagian besar informan memutuskan untuk menerima inovasi ini karena telah memiliki kapabilitas teknologi secara personal 
yang baik, sementara bagi sebagian informan yang merasa tidak cakap menggunakan teknologi, inovasi layanan online via WhatsApp masih dirasa memberatkan.

Berdasarkan hasil penelitian ini, diketahui bahwa proses difusi inovasi tidak bisa dilakukan dengan perubahan secara signifikan atau dipaksa mengikuti ketentuan yang ada, melainkan harus melalui tahap transisi yang terencana matang disertai sosialisasi agar masyarakat dapat mempersiapkan diri. Innovator, atau dalam hal ini pihak Disdukcapil Kota Samarinda juga harus memahami bentuk komunikasi yang tepat untuk target pengadopsi potensial sehingga bisa menyebarkan pesan persuasif sesuai saluran yang tepat. Penelitian selanjutnya dapat mempertimbangkan latar belakang informan khususnya usia sebagai bagian dari analisis, sebab penelitian ini menemukan perbedaan cara pandang dan persepsi terhadap adopsi inovasi antara informan yang berbeda generasi usia. Selain itu, kemampuan personal individu dalam menggunakan teknologi menjadi faktor utama dalam keputusan adopsi. Dalam hal ini, literasi digital menjadi pesan utama yang harus diperhatikan dalam setiap sosialisasi inovasi khususnya terkait pemanfaatan teknologi internet.

\section{DAFTAR PUSTAKA}

Aji, G. G., \& Dharmawan, A. (2020). E-Government to Improve Public Service in Village Difussion of Smart Kampung Innovation in Banyuwang. Advances in Social Science, Education and Humanities Research, 226(Icss), 347-351. https://doi.org/10.2991/icss-18.2018.71

Akadun. (2009). Teknologi Informasi Administrasi. Alfabeta.

Akça, Y., \& Özer, G. (2014). Diffusion of innovation theory and an implementation on enterprise resource planning systems. International Journal of Business and Management, 9(4), 92-114. https://doi.org/10.5539/ijbm.v9n4p92

Andrian, B. (2020). PARADIGMA KOMUNIKASI PEMBANGUNAN (Studi Pembangunan Pada Masyarakat Agrarisdi Sambas). ICRHD: Journal of International Conference On Religion, Humanity and Development, 217-226.

Arafah, Y., \& Winarso, H. (2020). Peningkatan dan Penguatan Partisipasi Masyarakat dalam Konteks Smart City. Tataloka, 22(1), 27-40. https://doi.org/10.14710/tataloka.22.1.27-40

Ardianto, E., Komala, L., \& Karlinah, S. (2014). Komunikasi Massa: Suatu Pengantar. Simbiosa Rekatama Media.

Arief, A., \& Yunus Abbas, M. (2021). Kajian Literatur (Systematic Literature Review): Kendala Penerapan Sistem Pemerintahan Berbasis Elektronik (SPBE). PROtek: Jurnal Ilmiah Teknik Elektro, 8(1), 1-6. https://doi.org/10.33387/protk.v8i1.1978

Arjita, U. A. (2017). E-Government Sebagai Bagian Dalam Smart City. Seminar Nasional IPTEK Terapan (SENIT) 2017, 15-17.

As'Adi, M. H. (2020). Difusi Inovasi dan Adopsi Inovasi 99design.com (Studi Kasus di Yayasan Pondok Pesantren Wahid Hasyim Yogyakarta). Lisyabab, 1(2), 211-232.

Asosiasi Penyedia Jaringan Internet Indonesia. (2019). Penetrasi \& Profil Perilaku Pengguna Internet Indonesia 2018. In APJII. www.apjii.or.id

Aw, S. (2016). Komunikasi Interpersonal. Graha Ilmu.

Batool, S., Gill, S. A., Javaid, S., \& Khan, A. J. (2021). Good Governance via E-Governance: Moving towards Digitalization for a Digital Economy. Review of Applied Management and Social Sciences (RAMSS), 4(4), 823-836. https://doi.org/10.47067/ramss.v4i4.186

Creswell, J. M. (2018). Research Design: Pendekatan Metode Kualitatif, Kuantitatif, dan Campuran (Edisi Keem). Pustaka Pelajar.

Dearing, J. W., \& Cox, J. G. (2018). Diffusion of innovations theory, principles, and practice. Health Affairs, 37(2), 183-190. https://doi.org/10.1377/hlthaff.2017.1104

Doni. (2021). Warga Samarinda Tak Perlu Lagi ke Disdukcapil, Cukup Via WhatsApp. Dinas Komunikasi Dan Informatika Kota Samarinda.

Effendy. (2003). Ilmu Teori dan Filsafat Komunikasi. PT Citra Aditya Bakti. 
Fakhruzzaman, M. N., \& Dimitrova, D. V. (2020). Factors influencing e-government adoption in indonesia: The importance of perceived risk. Journal of Advanced Research in Dynamical and Control Systems, $12(6 \quad$ Special $\quad$ Issue), $125-131$. https://doi.org/10.5373/JARDCS/V12SP6/SP20201015

Fazil, M., Zulham, \& Mardhiah, A. (2018). Karakteristik Inovasi Teknologi Informasi dan Komunikasi Pemerintahan Desa di Kota Lhokweumawe. Prosiding Konferensi Nasional Komunikasi, 02(01), 479-487. http://pknk.org/index.php/PKNK/article/view/47/52

Febriana, K. A., \& Setiawan, Y. B. (2016). Komunikasi Dalam Difusi Inovasi Kerajinan Enceng Gondok di Desa Tuntang, Kabupaten Semarang. The Messenger, 8(1), 17-26.

Frost, \& Sullivan. (2014). Strategic Opportunity Analysis of the Global Smart City Market. https://dsimg.ubm-us.net/envelope/153353/295862/1391029790_strategic_opportunity.pdf

Ghofar, M. (2017). Samarinda Terpilih Menuju “Smart City Indonesia." Kaltim.Antaranews.Com.

Giffinger, R. C., Fertner, H., Kramar, H., Kalasek, R., Pichler-Milanovic, N., \& Meijers, E. (2007). Smart cities: Ranking of Euro- pean medium-sized cities. http://www.smartcities.eu/download/smart_cities_final_report.pdf

Hasibuan, A., \& Sulaiman, O. K. (2019). Smart City, Konsep Kota Cerdas sebagai Alternatif Penyelesaian Masalah Perkotaan Kabupaten/Kota, di Kota-Kota Besar Provinsi Sumatera Utara. Buletin Utama Teknik, 14(2), 127-135.

Imran, M., \& Armawan, I. (2019). OPTIMALISASI SMART CITYSEBAGAI MEDIA KOMUNIKASI PEMBANGUNAN DI INDONESIA. Jurnal Komunikasi Pembangunan, 17(1), 81-85. https://journal.ipb.ac.id/index.php/jurnalkmp/article/view/26592/17167

Indrajit, R. E. (2004). E-Government Strategi Pembangunan Dan Pengembangan Sistem Pelayanan Publik Berbasis Teknologi Digital. Andi Offset.

Istyanto, N. P., \& Nasrulloh, M. (2019). Disruptif Teknologi E-Government terhadap Pelayanan Publik Tradisional Masyarakat Surabaya di Era Industri 4.0. INTEGER: Journal of Information Technology, 4(2), 1-11. https://doi.org/10.31284/j.integer.2019.v4i2.687

Juniriantio, E., \& Fadhliana, N. R. (2019). Pengembangan Aplikasi Antrian Online Realtime Samarinda. Sebatik, 23(2), 513-516.

Kaya, T., Sağsan, M., Medeni, T., Medeni, T., \& Yıldız, M. (2020). Qualitative analysis to determine decision-makers' attitudes towards e-government services in a De-Facto state. Journal of Information, Communication and Ethics in Society, 18(4), 609-629. https://doi.org/10.1108/JICES-05-2019-0052

Laenens, W., Van den Broeck, W., \& Mariën, I. (2018). Channel choice determinants of (digital) government communication: A case study of spatial planning in Flanders. Media and Communication, 6(4), 140-152.

Lazar, J., Feng, J. H., \& Hochheiser, H. (2017). Research methods in human-computer interaction. Morgan Kaufmann.

Lean, O. K., Zailani, S., Ramayah, T., \& Fernando, Y. (2020). Factors influencing intention to use egovernment services among citizens in Malaysia. International Journal of Information Management, 29(2009), 458-475. https://doi.org/10.1016/j.ijinfomgt.2009.03.012

Lim, Y., Edelenbos, J., \& Gianoli, A. (2019). Identifying the results of smart city development: Findings from systematic literature review. Cities, 95. https://doi.org/https://doi.org/10.1016/j.cities.2019.102397

Mechant, P., \& Walravens, N. (2018). E-government and smart cities: Theoretical reflections and case studies. Media and Communication, 6(4Theoretical Reflections and Case Studies), 119-122. https://doi.org/10.17645/mac.v6i4.1848

Meiyanti, R., Utomo, B., Sensuse, D. I., \& Wahyuni, R. (2019). E-Government Challenges in Developing Countries: A Literature Review. 6th Int. Conf. Cyber IT Serv. Manag. CITSM 2018, $1-6$. 
Miles, M. B., \& Huberman, A. M. (1994). Qualitative Data Analysis: An Expanded Sourcebook (2nd Editio). Sage Publications.

Rahayu, M. (2021). Masa Pandemi, Jumlah Permohonan Berkas Layanan di Disdukcapil Samarinda Menurun. RRI.

Rahmawati, M. P., \& Fatchuriza, M. (2021). Inovasi Pelayanan Administrasi Kependudukan Dalam Genggaman (Pak Dalman) Berbasis Aplikasi Di Kabupaten Kendal. AS-SIYASAH: Jurnal Ilmu Sosial ..., 6(2), 28-39. https://ojs.uniska-bjm.ac.id/index.php/Asy/article/view/5647

Rogers, E. M. (2003). Diffusion of Innovations (Fifth Edit). FREE PRESS.

Rusadi, U. (2014). Makna Dan Model Komunikasi Pembangunan. Jurnal Studi Komunikasi Dan Media, 18(1), 89. https://doi.org/10.31445/jskm.2014.180105

Sabani, A., Deng, H., \& Thai, V. (2019). Evaluating the development of E-government in Indonesia. ACM International Conference Proceeding Series, 254-258. https://doi.org/10.1145/3305160.3305191

Sabani, A., Farah, M. H., \& Sari Dewi, D. R. (2019). Indonesia in the spotlight: Combating corruption through ICT enabled governance. Procedia Computer Science, 161, 324-332. https://doi.org/10.1016/j.procs.2019.11.130

Sahin, I. (2006). Detailed review of Rogers' diffusion of innovations theory and educational technology-related studies based on Rogers' theory. The Turkish Online Journal of Educational Technology, 5(2), 14-23.

Saleh, A. (2010). Model Komunikasi dan Penyuluhan Perkembangan Pembangunan Mendukung Pengembangan Masyarakat Berkelanjutan. http://repository.ipb.ac.id/handle/123456789/32162

Soetomo. (2013). Strategi-Strategi Pembangunan Masyarakat. Pustaka Pelajar.

Sugiyono. (2017). Metode Penelitian Kuantitatif, Kualitatif, dan R\&D. Alfabeta, CV.

Szarek-Iwaniuk, P., \& Senetra, A. (2020). Access to ICT in Poland and the co-creation of Urban space in the process of modern social participation in a smart city-a case study. Sustainability (Switzerland), 12(5). https://doi.org/10.3390/su12052136

Taufik, M. (2017). Merdeka Mesiotda - Samarinda terpilih sebagai kota kategori Smart City. Merdeka.Com.

Tryanti, W., \& Frinaldi, A. (2019). EFEKTIVITAS IMPLEMENTASI E-GOVERNMENT DALAM PELAYANAN KEPENDUDUKAN DI DINAS KEPENDUDUKAN DAN PENCATATAN SIPIL KOTA PADANG. Ranah Research: Journal of Multidisciplinary Research and Development, 1(3), 424-435.

Utomo, C. E. W., \& Hariadi, M. (2016). Strategi Pembangunan Smart City dan Tantangannya bagi Masyarakat Kota. Jurnal Strategi Dan Bisnis, 4(2), 159-176.

Weerakkody, V., Irani, Z., Kapoor, K., \& Sivarajah, U. (2016). Citizen Adoption of E-Government Services : Exploring Citizen Perceptions of Online Services in the US and UK Open data and its usability: an empirical view from the Citizen's perspective. Information Systems Frontiers, 2021(July). https://doi.org/10.1007/s10796-016-9679-1

Wibowo, I. T. (2019). Indonesian Treasury Review Proses Difusi Inovasi Program Sistem Aplikasi Keuangan. Indonesian Treasury Review, 4(4), 323-337.

Widodo, N. (2016). Pengembangan e-Government di Pemerintahan Daerah dalam Rangka Mewujudkan Smart City (Studi di Pemerintah Daerah Kota Malang). Jurnal Ilmiah Administrasi Publik, 2(4), 227-235. https://doi.org/10.21776/ub.jiap.2016.002.04.15 